\title{
ŠIUOLAIKINIS KARDIOGENINIO ŠOKO GYDYMAS
}

\author{
Ieva Rudinskaitė ${ }^{1}$, Giedrius Navickas ${ }^{2,4}$, Robertas Stasys Samalavičius ${ }^{1,3,4}$, Pranas Šerpytis $^{1,2,3,4}$ \\ ${ }^{I}$ Vilniaus universiteto Medicinos fakultetas, ${ }^{2}$ Vilniaus universiteto ligonines Santaros kliniku \\ Širdies ir kraujagysliu ligu klinika, ${ }^{3}$ Vilniaus universitetas, Klinikines medicinos institutas, \\ Skubios medicinos klinika, ${ }^{4}$ Vilniaus universiteto Santaros klinikos
}

Raktažodžiai: kardiogeninis šokas, simpatomimetikai, vazopresoriai, inotropai.

\begin{abstract}
Santrauka
Kardiogeninis šokas $(K \breve{S})$ - tai klinikinè būklè, kuriai būdingas sumažèjęs širdies minutinis tūris, hipoperfuzija, dauginis organų nepakankamumas ir didelis mirtingumas. Ūmus miokardo infarktas yra pagrindinè KŠ priežastis, kuri sudaro apie trečdalị visų KS̆ atvejų. Klinikinis K $\breve{S}$ apibrežimas dažniausiai remiasi hemodinamikos kriterijais ir hipoperfuzijos požymiais. Siekiant atkurti hemodinamiką ir pagerinti organų perfuziją, KŠ gydymui skiriami vazopresoriai ir inotropai. Mokslinèje literatūroje nurodoma, kad norepinefrinas yra pirmo pasirinkimo vaistas KS̆ gydymui, o esant mažam širdies minutiniam tūriui, pridedami inotropai, dažniausiai - dobutaminas ir milrinonas. Tikslas - apžvelgti 2016-2021m. publikuotų mokslinių straipsnių, aprašančių šiuolaikinį kardiogeninio šoko gydymą, duomenis.

Metodika. Atlikta sisteminė mokslinès literatūros apžvalga. Duomenys buvo renkami PubMed, ScienceDirect, ClinicalKey, Cochrane Library duomenų bazèse. Analizei buvo naudojami viso teksto straipsniai, kuriu pavadinimas, santrauka ir raktažodžiai atitiko apžvalgos tikslą. Naudoti raktažodžiai: cardiogenic shock, inotropes, vasopressors. Analizuotos tik anglų kalba skelbtos 2016-2021m. publikacijos. Literatūros apžvalgai atrinkta 19 straipsnių. Rezultatai. Esant hipotenzijai ar vazoplegijai pirmo pasirinkimo vaistas - norepinefrinas. Jei kraujospūdis normalus, skiriami inotropai. Norepinefrino skyrimas susijęs su mažesniu pacientų mirtingumu, retesnèmis aritmijomis ir rečiau išsivystančiu refrakteriniu kardiogeniniu šoku. Literatūroje nurodoma, kad norepinefrino ir levosimendano ar dobutamino kombinacija yra tinkama kardiogeninio šoko gydymui. Epinefrinas dèl $\alpha$ ir $\beta$ adrenerginio poveikio miokardui yra mažiausiai saugus ir susijęs su didesniu mirtingumu. Dopaminas susijęs su dažnesnèmis
\end{abstract}

aritmijomis, tachikardija ir didesniu mirtingumu. Levosimendanas pasižymi teigiamu inotropiniu poveikiu ir Tako-tsubo kardiomiopatijos metu gali būti skiriamas kaip alternatyva katecholaminams. Šiuo metu trūksta randomizuotų, didelès apimties tyrimų, kuriuose būtų nagrinèjami skirtingi KS̆ gydymo metodai.

\section{Ivadas}

Kardiogeninis šokas (KŠ) - tai klinikinè būklè, kuriai būdingas sumažèjęs širdies minutinis tūris (ŠMT), hipoperfuzija, dauginis organų nepakankamumas ir didelis mirtingumas [1]. Ūmus miokardo infarktas (ŪMI) yra pagrindinè KŠ priežastis, kuri sudaro apie trečdalį visų KS̆ atvejų [2]. Literatūroje nurodoma, kad KŠ išsivysto pažeidus $>40 \%$ funkcionuojančio miokardo [3]. Mechaninès komplikacijos, tokios kaip igytas skilvelio pertvaros defektas, laisvos sienos ir papiliarinio raumens plyšimas arba disfunkcija su ūmia mitraline regurgitacija, Tako-tsubo kardiomiopatija yra retesnès KŠ priežastys [3-5]. KŠ diagnozuojamas, kai tenkinami visi iš išvardintų kriterijų: 1) sistolinis arterinis kraujo spaudimas (sAKS) $<90 \mathrm{~mm} \mathrm{Hg} \geq 30 \mathrm{~min}$ arba reikalingos farmakologinès ar/ir mechaninès sAKS palaikymo $\geq 90 \mathrm{~mm}$ Hg priemonès, 2) klinikiniai plaučių edemos ar padidejusio kairiojo skilvelio (KS) prisipildymo slègio požymiai (plaučiu kapiliarų pleištinis spaudimas (PKPS) $>18 \mathrm{~mm} \mathrm{Hg}, 3$ ) yra bent vienas sutrikusios organų perfuzijos požymis: sutrikusi sąmonè, šalta, drègna oda bei galūnès, šlapimo išsiskyrimas $<30 \mathrm{ml} / \mathrm{val}$., serumo laktato koncentracija $>2,0 \mathrm{mmol} / \mathrm{l}$. Sumažèjęs širdies indeksas (ŠI) $(\leq 2,2 \mathrm{~L} / \mathrm{min})$ yra papildomas KŠ diagnostinis kriterijus [5].

KŠ yra pagrindinè pacientų su ŪMI mirties priežastis [5]. Remiantis IABP-SHOCK II (angl. - Intraaortic Balloon Pump in Cardiogenic Shock II) ir kitų tyrimų duomenimis, nepaisant inotropų ir vazopresorių skyrimo, taikytos intraaortinès balioninès kontrapulsacijos, pacientu su ŪMI mirštamumas siekia apie 40-80\% [5,6]. KŠ dèl platesnio miokardo pažeidimo ir greitesnès ląstelių nekrozès yra 
dažnesnis tarp pacientų su STEMI (angl. - ST-elevation myocardial infarction), tačiau NSTEMI (angl. - Non-STelevation myocardial infarction) pacientų mirtingumas dèl vyresnio amžiaus, labiau pažengusių trijų vainikinių arteriju (VAL) ir gretutinių ligų, sumažejusios išmetimo frakcijos (IF) ir rečiau atliekamų koronarografijų yra 10\% didesnis [5]. Pacientai su KŠ dažniausiai miršta per pirmąsias 3 dienas, todèl sprendimas dèl gydymo taktikos turi būti priimtas kaip galima greičiau $[1,6]$.

Siekiant atkurti hemodinamiką ir pagerinti organų perfuziją yra skiriami vazopresoriai, kurie sukelia vazokonstrikciją ir sisteminį kraujagyslių pasipriešinimą, bei inotropai, kurie skatina širdies kontraktilinę funkciją, todèl didèja vidutinis arterinis kraujospūdis (VAS) ir gereja vidaus organų kraujotaka $[2,5,7]$.

Pagrindinis KŠ gydymo tikslas - atkurti pakankamą makro- ir mikrocirkuliaciją, siekiant užtikrinti pastovų deguonies tiekimą ląsteliniame lygmenyje bei reguliuoti sistemini imuninị atsaką, kad būtų išvengta funkcinio ir morfologinio ląstelių pažeidimo, taip užkertant kelią organų disfunkcijai, o véliau ir nepakankamumui [7]. Apie inotropų ir vazopresoriu naudojimą KŠ gydymui pradèti kalbèti dar 1950m., tačiau jų skyrimas išlieka kontraversiškas [6]. Mokslinèje literatūroje nurodoma, kad norepinefrinas (NE) yra pirmo pasirinkimo vaistas KŠ gydymui, o esant mažam ŠMT pridedami inotropai, iš kurių dažniausiai naudojami - dobutaminas ir milrinonas $[2,8,9]$. Vis dèlto šie vaistai yra susiję su aritmijomis, jų poveikyje didejjant kontraktiliš̌kumui, pokrūviui ar mažejant koronarų perfuzijai gali padidèti miokardo deguonies poreikis, todèl klinikineje praktikoje inotorpai ir vazopresoriai turètų būti skiriami mažiausiomis dozėmis ir kaip galima trumpiau (3 lentelè) $[2,3,6]$.

Tikslas - apžvelgti 2016-2021m. publikuotų mokslinių straipsnių, aprašančių šiuolaikinị kardiogeninio šoko gydymą, duomenis.

\section{Tyrimo medžiaga ir metodai}

Atlikta mokslinès literatūros apžvalga. Duomenys buvo renkami PubMed, ScienceDirect, ClinicalKey, Cochrane Library duomenų bazèse. Analizei buvo naudojami viso teksto straipsniai, kurių pavadinimas, santrauka ir raktažodžiai atitiko apžvalgos tikslą. Naudoti raktažodžiai: cardiogenic shock, inotropes, vasopressors. Analizuotos tik anglų kalba skelbtos 2016-2021 m. publikacijos. Literatūros apžvalgai atrinkta 19 straipsnių.

\section{Tyrimo rezultatai}

Vazopresoriai. Vazopresoriai skirstomi ị dvi grupes: 1) adrenerginiai: norepinefrinas, fenilefrinas, epinefrinas, dopaminas, dobutaminas ir izoproterenolis; 2) neadrener- giniai: angiotenzinas II ir azoto oksido (NO) inhibitoriai, tačiau daugelis vaistų pasižymi ir vazopresiniu, ir inotropiniu poveikiu [3]. Remiantis gairèmis bei ekspertų išvadomis, pirmo pasirinkimo vazopresoriai šoko (kardiogeninio, sepsinio, hipovoleminio) gydymui yra NE arba dopaminas, tačiau mokslinių tyrimų, kuriuose būtų lyginamas vazopresorių veiksmingumas KŠ metu, trūksta [9].

Norepinefrinas. Tai $\alpha$-adrenerginių receptorių agonistas, kuris pirmą kartą KŠ gydymui pradètas naudoti 1953 metais [6]. NE poveikyje dideja sisteminis kraujospūdis, pulsas, periferinis kraujagyslių pasipriešinimas bei sistolinis tūris (ST). NE naudojamas kaip pirmo pasirinkimo kraujospūdị didinantis vaistas (IIB klasė, B įrodymų lygis), skiriamas dažniau nei dopaminas $[1,3]$. Remiantis randomizuoto SOAP II (angl. Sepsis Occurrence in Acutely Ill Patients II) tyrimo, kurio metu pacientams su KS̆ buvo skirtas dopaminas arba NE ir kt. studijų duomenimis, nustatyta, kad NE padeda reikšmingai sumažinti mirtingumą, tačiau taikant mechaninès kraujotakos palaikymo priemones (MKPP), pavyzdžiui, Impella, stebimi priešingi rezultatai. Pastebèta, kad refrakterinis KŠ skiriant NE išsivysto rečiau. Esant žemam kraujospūdžiui, Europos kardiologų draugijos (EKD) ūmaus ir lètinio širdies nepakankamumo ( ̌́N) gairès (2021 m.) rekomenduoja NE kombinaciją su inotropu $[1,5]$.

Epinefrinas. Tai vazopresorių grupès atstovas, kuris, veikdamas $\beta 2$ receptorius lygiuosiuose raumenyse, didina ST ir ŠMT bei mažina sisteminị kraujagyslių pasipriešinimą (SKP). Epinefrino poveikyje dideja plaučių kraujagyslių pasipriešinimas ir dešiniojo skilvelio pokrūvis. Padažnejjus šrdies ritmui, padideja miokardo deguonies poreikis, todèl dèl galimo išemijos išsivystymo epinefrinas nèra skiriamas dekompensuoto širdies nepakankamumo ( $\breve{S} N)$ paūmėjimo metu [3]. B. Levy ir kt. paskelbé pirmają randomizuotą studiją, kurioje buvo lyginamas epinefrino ir NE poveikis KS pacientams po ŪMI, tačiau dèl dažnesnio refrakterinio KS̆, epinefrino gr. (epinefrino gr. $37 \%$ vs. $\mathrm{NE}$ gr. $7 \%$, p=0,008) tyrimas buvo nutrauktas. Pastebèta, kad epinefrinas susijęs su didesniu širdies susitraukimų dažniu ( $\breve{S} S D$ ) ir laktatacidoze [10]. Prospektyvinis 216 pacientų su KS̆ tyrimas atskleidè, kad iš vazopresorių ir inotropų, būtent, epinefrinas yra susijęs su didesniu 90 dienu mirtingumu ir prastesniais širdies bei inkstų funkcijos rodikliais [5]. Remiantis 16 studijų metaanalizès rezultatais, $\mathrm{KS}$ metu epinefrinas 3,3 karto padidina mirties tikimybę, palyginus su kitais vaistais. Autoriu teigimu, siekiant sumažinti mirtingumą bei išvengti pavojingų komplikacijų skiriant epinefriną, NE ir dobutamino ar levosimendano kombinacija yra saugesne KŠ gydymo alternatyva [5].

Dopaminas. Tai katecholaminas, natūralus NE ir epinefrino pirmtakas, kurio poveikis priklauso nuo dozès: skiriamas 
mažomis dozėmis jungiasi prie dopaminerginių receptorių ir sukelia vazodilataciją (ypač blužnies ir inkstų arterijose), o didelèmis dozėmis veikia kaip $\beta 1$ agnosistas ir pasižymi inotropiniu poveikiu. Skiriamas dar didesnėmis dozėmis, dopaminas stimuliuoja $\alpha$ receptorius, todèl sukelia periferiniu kraujagyslių vazokonstrikciją ir didina kraujospūdi [6]. KS̆ metu dopamino poveikyje padažneja pulsas, dideja ŠMT ir ST, KS diastolinis užpildymo slègis bei sumažèja SKP [3]. Remiantis anksčiau aptarto SOAP II tyrimo duomenimis, nustatyta, kad dopaminas yra susijęs su dažnesnèmis aritmijomis ir didesniu mirtingumu 28 dienų laikotarpiu $[3,5]$. Atsiradusios tachikardijos ir vazokonstrikcijos poveikyje didejja deguonies poreikis, sutrinka deguonies tiekimas, o tai gali sukelti išemiją ir aritmijas. Jei KŠ metu reikalinga VAS korekcija, EKD $2021 \mathrm{~m}$. gairès nurodo, kad NE, lyginant su dopaminu, yra tinkamesnis pasirinkimas [1].

Vazopresinas. Tai hormonas, kuris, prisijungęs prie kraujagyslių lygiuosiuose raumenyse esančių V1 receptorių, sukelia vazokonstrikciją, o stimuliuodamas V2 receptorius, skatina vandens reabsorbciją inkstų kanalèliuose (antidiuretinis poveikis). Lyginant su epinefrinu, pastebèta, kad esant kardiopulmoniniam nepakankamumui, vazopresinas pasižymi panašiu poveikiu gaivinant pacientus su skilvelių virpejjimu arba elektromechanine disociacija ir yra veiksmingesnis, esant asistolijai. Vazopresinas nedidina plaučių arterijų spaudimo, todèl gali būti skiriamas pacientams su dešiniojo skilvelio nepakankamumu [11]. Dẻl aortos vožtuvo stenozès išsivystęs KŠ, kai yra išsaugota IF, taip pat gali būti gydomas vazopresinu, nes tai nuo pokrūvio priklausoma būklè [12]. Literatūroje nurodoma, kad vazopresinas leidžia sumažinti NE poreikị pacientams su hipotenzija, kai yra implantuotas kairiji skilvelị pavaduojantis prietaisas (KSPP) [6]. Vis dèlto vazopresinas nèra rekomenduojamas ŪMI sukelto KŠ gydymui, nes jo koncentracija (pasireiškia kaip atsakas ị MI sukeltą stresą) yra 100 kartų aukštesnè (fiziologinè vazopresino koncentracija svyruoja nuo $1 \mathrm{iki} 5 \mathrm{pg} / \mathrm{ml}$ ) ir po reperfuzijos iki pradinio lygio greitai negrįžta [13]. NE turètų būti pirmo pasirinkimo vaistas pacientams su hipotenzija ir vazoplegija, o vazopresinas rekomenduojamas, kai reikia didesnių NE dozių arba esant sutrikusiam širdies ritmui [6]. Šiuo metu dar trūksta randomizuotų tyrimų, kuriuose būtų analizuojamas vazopresino poveikis K $\breve{S}$ gydymui.

Inotropai. Kai yra KS disfunkcija, sumažejęes ŠMT ir sAKS ( $<90 \mathrm{~mm} \mathrm{Hg})$, EKD $2021 \mathrm{~m}$. gairès rekomenduoja intraveninių inotropų skyrimą (IIB klasè, C įrodymų lygis) [1]. Idealus inotropas pasižymi šiomis savybèmis: didina ŠMT, mažina skilvelio prisipildymo slègị ir mirtingumą, nesukelia šalutinių reiškinių [6].

Dobutaminas. Šiuo metu pačiu tinkamiausiu inotropu KŠ gydymui laikomas dobutaminas, nes jo poveikyje didejja
(ŠSD), ST ir ŠMT, sumažèja KS prisipildymo slègis, kraujospūdis bei SKP [3]. Prospektyvinès studijos, kurios metu 30 KS pacientų buvo skirta norepinefrino-dubutamino arba epinefrino infuzija, rezultatai parode, kad abiejose grupèse ŠI, arterinio kraujospūdžio, deguonies suvartojimo, inkstų funkcijos ir mirtingumo rodikliai buvo panašūs, tačiau norepinefrino-dobutamino kombinacija KŠ metu yra saugesnè $[5,6]$. Remiantis 14 tyrimų metaanalizès duomenimis, pacientu su sunkiu ŠN, kuriems buvo skirtas dobutaminas, mirtingumas buvo didesnis, nei taikant standartini gydymą arba placebą [6]. Mokslininkai hipotetizuoja, jog padidejęes mirtingumas skiriant dobutaminą gali būti padidèjusio deguonies suvartojimo ir miokardo išemijos pasekmè. Pastebėta, kad lyginant su enoksimonu, dopamino skyrimas susijęs su dažnesnèmis supraventrinkulinėmis ir ventrikulinėmis tachikardijomis [5].

Milrinonas ir enoksimonas. Milrinonas yra fosfodiesterazès 3 (PDE3) inhibitorius, kuris slopina cAMP skilimą [3]. Priešingai nei katecholaminai, milrinonas neveikia ŠSD, todèl nedidina deguonies poreikio miokarde [6]. PROMISE (angl. Prospective Randomised Milrinone Survival Evaluation) studijos duomenys parode, kad milrinono skyrimas pacientams su sunkiu lètiniu ŠN ir KS disfunkcija susijęs su dažnesnèmis hospitalizacijomis ir didesniu 6 mèn. laikotarpio mirtingumu, nei placebo grupejje [5]. Kitas mažos apimties randomizuotas kontroliuojamas tyrimas, kuris vertino enoksimono ir levosimendano poveikị refrakterinio KS gydymui, atskleidè, kad išskirtinai enoksimonas susijęs su dauginiu organų nepakankamumu [5]. EKD 2017m. miokardo infarkto su ST segmento pakilimu diagnostikos ir gydymo gairèse nurodoma, kad PDE3 inhibitoriai nėra rekomenduojami pacientams su STEMI [14].

Levosimendanas. Levosimendanas yra kalcio jautrintojas, kuris pasižymi teigiamu inotropiniu poveikiu - didindamas miokardo jautrumą intraceliuliniam kalciui, atpalaiduoja lygiuosius raumenis ir skatina širdies kontraktilinę funkciją [3]. Levosimendanas, taip pat kaip milrinonas, nedidina deguonies poreikio, pasižymi geresniu saugumo profiliu, nesukelia aritmijų, o hemodinaminis poveikis gali trukti iki 7-9 dienu [5]. Remiantis randomizuotos SURVIVE (angl. The Survival of Patients With Acute Heart Failure in Need of Intravenous Inotropic Support) studijos, kurios imtį sudare 1327 pacientai, rezultatais, nustatyta, kad levosimendanas, palyginus su dobutaminu, pasižymi stipresniu vazodilataciniu poveikiu (inodiliatorius), tačiau nesumažina mirtingumo. Panašūs rezultatai aprašomi ir kituose tyrimuose [3]. 648 KŠ pacientų su ŪMI metaanalizè atskleidè, kad levosimendanas, lyginant su standartiniais gydymo būdais ar placebu, susijęs su sumažějusiu kraujo spaudimu plaučių arterijose bei galiniu ST, padidejjusiu ŠI ir nežymiai sumažějusiu mirtingumu tiria- 
mojoje grupeje ( $36 \%$ levosimendano gr. vs 53\% kontrolinèje

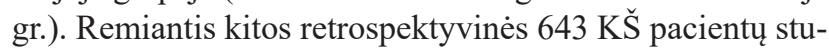
dijos duomenimis, pastebèta, kad vazopresoriaus derinimas su inodiliatoriumi, tokiu kaip levosimendanas, dobutaminas ar PDE3 inhibitorius, susijęs su mažesniu mirtingumu, nei skiriant tik vazopresorius [5].

Nors sunkaus KS̆ atveju rekomenduojami inotropiniai adrenerginiai agonistai, tokie kaip dobutaminas ir epinefrinas, Tako-tsubo kardiomiopatijos metu, atsižvelgiant i ligos patofiziologiją, katecholaminus ir inotropus reikia skirti atsargiai. Mokslininkų teigimu, skiriant katecholaminus, pacientų su Tako-Tsubo kardiomiopatija mirtingumas siekia 20 proc., todèl kaip alternatyva nurodomi kalcio jautrintojai, pvz., levosimendanas. Šis vaistas pasižymi keliomis teigiamomis inotropinèmis savybèmis: 1) didèja troponino $\mathrm{C}$ jautrumas kalcio jonams, 2) pasireiškia vazodilatacinis poveikis, nes atidaromi ATP valdomi $\mathrm{K}+$ kanalai, 3) susijęs su PDE3 slopinimu [4].

Naujausioje Cochrane apžvalgoje nagrinèjami 19 atsitiktinių imčių tyrimų, kai dèl ŪMI, ŠN ar kardiochirurginès operacijos išsivyste K $\breve{S}$, bei vertinamas vazodilatatorių ir inotropų poveikis mirtingumui. Nustatyta, kad levosimendanas, palyginus su dobutaminu, gali padèti laikinai sumažinti trumpalaikị mirtingumą dẻl visų priežasčių, tačiau ilgalaikio poveikio nepastebèta. Remiantis tyrimų duomenimis, pacientų, kuriems atitinkamai buvo skirtas levosimendanas (vs dobutaminas), levosimendanas (vs enoksimonas) ir enoksimonas (vs dobutaminas) hospitalizacijos laikas intensyviosios terapijos skyriuje buvo trumpesnis. Pastebètas teigiamas levosimendano poveikis ŠI, VAS ir PKPS, lyginant su dobutaminu, enoksimonu, placebo, bei epinefrino, lyginant su NE. Cochrane apžvalgoje nurodoma, kad levosimendanas (vs enoksimonas), norepinefrinas-dobutaminas ir NE, lyginant su epinefrinu, pasižymi geresniu saugumo profiliu, tačiau reikia pabrèžti, kad šiuo metu trūksta randomizuotų, didelès apimties tyrimų, kuriuose būtų nagrinejjami skirtingi KŠ gydymo metodai [7].

KS̆ gydymas mechaninėmis priemonėmis. Pagal prijungimo trukmę, MKPP skirstomos ị dvi grupes: 1) trumpalaikès: intraaortine balioninè kontrapulsacija (IABK), venoarteriné ekstrakorporalinė membraninè oksigenacija (VA - EKMO) ir 2) ilgalaikès - dirbtiniai širdies skilveliai.

1 lentelè. Mechaninių kraujotaką palaikančių priemonių indikacijos [1].

* angl. Bridge to candidacy, BTC

** angl. Destination therapy, DT

SPP - skilveli pavaduojantis prietaisas; KSPP - kairiji skilveli pavaduojantis prietaisas; BiVAD (angl. biventricular assist device) - abu sirdies skilvelius pavaduojanti sistema; TDS̆ - totaliné dirbtinè širdis.

\begin{tabular}{|l|l|}
\hline $\begin{array}{l}\text { Tiltas ị sprendimą } \\
\text { (Tiltas ị tiltą) }\end{array}$ & $\begin{array}{l}\text { Trumpalaikès MKPP (EKMO arba Impella) naudojamos kardiogeninio šoko metu, kol hemodinamika ir or- } \\
\text { ganų-taikinių perfuzija tampa stabili, neịtraukiant ilgalaikių MKPP kontraindikacijų (smegenų pažeidimas po } \\
\text { gaivinimo); gali būti ̣̂vertintos papildomos gydymo galimybès, įskaitant ilgalaikị SPP ir širdies transplantaciją }\end{array}$ \\
\hline $\begin{array}{l}\text { Tiltas ị kitą spren- } \\
\text { dimą* }\end{array}$ & $\begin{array}{l}\text { MKPP (dažniausiai KSPP) naudojamos pagerinti organų-taikinių funkciją ir (arba) siekiant paciento tinkamumo } \\
\text { širdies transplantacijai }\end{array}$ \\
\hline $\begin{array}{l}\text { Tiltas ị transplan- } \\
\text { taciją }\end{array}$ & $\begin{array}{l}\text { MKPP (KSPP, BiVAD arba TDŠ) naudojamos palaikyti didelę mirties riziką prieš transplantaciją turinčio paciento } \\
\text { gyvybę, kol bus prieinamas donoro organas }\end{array}$ \\
\hline Tiltas ị pasveikimą & $\begin{array}{l}\text { MKPP (trumpalaikès arba ilgalaikės) naudojamos palaikyti paciento gyvybę, kol bus pakankamai atkurta širdies } \\
\text { funkcija }\end{array}$ \\
\hline $\begin{array}{l}\text { Tikslinė } \\
\text { terapija** }\end{array}$ & $\begin{array}{l}\text { Ilgalaikės MKPP (KSPP) naudojamos kaip transplantacijos alternatyva pacientams, sergantiems galutinès stadijos } \\
\text { ŜN, kurie netinka transplantacijai }\end{array}$ \\
\hline
\end{tabular}

2 lentelè. Pacientai, kuriems gali būti tinkamas kairịjị skilvelị pavaduojantis prietaisas [1].

KSPP gali būti implantuojamas pacientams, kuriems, nepaisant optimalaus medikamentinio ir mechaninio gydymo, išlieka sunkūs simptomai, nėra sunkios dešiniojo skilvelio disfunkcijos ir (ar) triburio vožtuvo regurgitacijos, stabilios psichosocialinės padėties, nėra kontraindikacijų (kontraindikuotinas ilgalaikis gydymas oraline antikoaguliacija, infekcija, sunki inkstų disfunkcija, skilvelinės aritmijos) ir yra bent vienas iš šių požymių:

- KSIF (liet. - kairiojo skilvelio išmetimo frakcija) $<25 \%$ ir negali mankštintis dèl ŠN arba, jei galima, atlikti kardiopulmoninị krūvio testą $\mathrm{VO}_{2}<12 \mathrm{ml} / \mathrm{kg} / \mathrm{min}$ ir (ar) $<50 \%$ numatytos vertès

$\bullet \geq 3$ hospitalizavimai dėl ŠN per pastaruosius 12 mèn., nesant akivaizdžių ŠN paūmèjimus sukeliančių veiksnių

- Priklausomybè nuo intraveninio gydymo inotropais arba laikinų MKPP

- Progresuojantis organų taikinių funkcijos sutrikimas (blogėjanti inkstų ir (ar) kepenų funkcija, II tipo plautinė hipertenzija, širdies kacheksija) dèl sumažèjusios perfuzijos ir ne dèl nepakankamo skilvelio prisipildymo spaudimo (PKPS $\geq 20 \mathrm{mmHg}$ ir sAKS $\leq 90$ $\mathrm{mmHg}$ ar $\breve{S} \mathrm{I} \leq 21 / \mathrm{min} / \mathrm{m} 2$ ) 
3 lentelè. Medikamentinis kardiogeninio šoko gydymas [5,6].

\begin{tabular}{|c|c|c|c|c|c|}
\hline Vaistas & Klasė, receptoriai & Dozè & Veikimo mechanizmas & $\begin{array}{l}\text { Ve i k i m o } \\
\text { pusperiodis }\end{array}$ & $\begin{array}{l}\text { Šalutinis } \\
\text { poveikis }\end{array}$ \\
\hline Norepinefrinas & $\begin{array}{l}\text { Katecholaminas } \\
\alpha 1+++++ \\
\beta 1+++ \\
\beta 2++ \\
D-\end{array}$ & $\begin{array}{l}\text { Infuzija } 5-20 \mu \mathrm{g} / \\
\min (\text { nuo } 0,5 \text { iki } 30 \\
\mu \mathrm{g} / \mathrm{min} \text { ) }\end{array}$ & $\begin{array}{l}\text { Inotropija, chronotropija, dromotropija, } \\
\text { vazokonstrikcija }\end{array}$ & $2-2,5 \mathrm{~min}$ & $\begin{array}{l}\text { Aritmijos, } \\
\text { bradikardija, pe- } \\
\text { riferine išemija, } \\
\text { vartojantiems } \\
\text { neselektyvius } \\
\beta \text {-blokatorius } \\
\text { gali pasireikšti } \\
\text { hipertenzija } \\
\end{array}$ \\
\hline Epinefrinas & $\begin{array}{l}\text { Katecholaminas } \\
\alpha 1++++ \\
\beta 1++++ \\
\beta 2+++ \\
\mathrm{D}-\end{array}$ & $\begin{array}{l}\text { Infuzija } 2-10 \mu \mathrm{g} / \\
\min \end{array}$ & $\begin{array}{l}\text { - Inotropija, chronotropija, dromotro- } \\
\text { pija, vazokonstrikcija } \\
\text { - Mažomis dozėmis stimuliuoja } \beta 1 \text { ir } \\
\beta 2 \text {, didesnėmis - } \alpha 1 \text { receptorius }\end{array}$ & $2 \mathrm{~min}$ & $\begin{array}{l}\text { Skilvelinės } \\
\text { aritmijos, } \\
\text { širdies išemija, } \\
\text { galvos smegenų } \\
\text { hemoragija dèl } \\
\text { hipertenzijos }\end{array}$ \\
\hline Dopaminas & $\begin{array}{l}\text { Katecholaminas } \\
\alpha 1+++ \\
\beta 1++++ \\
\beta 2++ \\
\mathrm{D}++++\end{array}$ & $\begin{array}{l}\text { Infuzija } \\
\text { Maža dozè }(2-5 \mu \mathrm{g} / \\
\mathrm{kg} / \mathrm{min}) ; \text { Vidutinè } \\
\text { dozè }(5-10 \mu \mathrm{g} / \mathrm{kg} / \\
\mathrm{min}) ; \text { Didelè dozè } \\
(10-20 \mu \mathrm{g} / \mathrm{kg} / \mathrm{min})\end{array}$ & $\begin{array}{l}\text { - Inotropija, chronotropija, dromotro- } \\
\text { pija, vazokonstrikcija } \\
\text { - Skiriant mažomis dozėmis, jungiasi } \\
\text { prie dopaminerginių receptorių } \rightarrow \\
\text { vazodilatacija } \\
\text { - Skiriant vidutinėmis dozėmis, } \\
\text { jungiasi prie } \beta 1 \text { receptorių, skatina } \\
\text { noradrenalino išsiskyrimą, todėl didèja } \\
\text { ŠMT } \\
\text { - Skiriant didelėmis dozėmis, veikia } \\
\alpha 1 \text { receptorius } \rightarrow \text { vazokonstrikcija } \\
\end{array}$ & $2 \mathrm{~min}$ & $\begin{array}{l}\text { Skilvelinės arit- } \\
\text { mijos, širdies ir } \\
\text { audinių išemija, } \\
\text { vartojantiems } \\
\text { neselektyvius } \\
\text { gali pasireikšti } \\
\text { sunki hiperten- } \\
\text { zija }\end{array}$ \\
\hline Dobutaminas & $\begin{array}{l}\text { Katecholaminas } \\
\alpha 1+ \\
\beta 1++++ \\
\beta 2++ \\
D-\end{array}$ & $\begin{array}{l}\text { Infuzija } \\
\text { Pradèti nuo } 2 \mu \mathrm{g} / \\
\mathrm{kg} / \mathrm{min} \text { ir titruoti iki } \\
\text { maksimalios } 40 \mu \mathrm{g} / \\
\mathrm{kg} / \mathrm{min} \text { dozès }\end{array}$ & $\begin{array}{l}\text { - Inotropija ir saiki vazodilatacija } \\
\text { - Skiriant mažomis } \\
\text { dozėmis } \rightarrow \text { vazodilatacija } \\
\text { - Skiriant didesnėmis dozėmis } \rightarrow \\
\text { stimuliuojamas miokardo kontraktiliš- } \\
\text { kumas }\end{array}$ & $2-3 \min$ & $\begin{array}{l}\text { Hipotenzija, ta- } \\
\text { chikardija, skil- } \\
\text { velinės aritmijos, } \\
\text { širdies išemija, } \\
\text { vartojantiems } \\
\text { neselektyvius } \\
\beta \text {-blokatorius } \\
\text { gali pasireikšti } \\
\text { hipertenzija } \\
\end{array}$ \\
\hline $\begin{array}{l}\text { Milrinonas/ } \\
\text { enoksimonas }\end{array}$ & $\begin{array}{l}\text { Fosfodiesterazès } 3 \\
(\mathrm{PDE} 3) \text { inhibitorius }\end{array}$ & $\begin{array}{l}\text { Boliusas } 50 \mu \mathrm{g} / \mathrm{kg} \text {, } \\
\mathrm{kartu} \text { su } 0,375-0,75 \\
\mu \mathrm{g} / \mathrm{kg} / \mathrm{min} \text { infuzija }\end{array}$ & $\begin{array}{l}\text { - Inotropija ir periferinė vazodilatacija } \\
\text { - Slopindamas PDE3, didina intraląs- } \\
\text { telinio cAMF kiekį ir klacio pasisavi- } \\
\text { nimą kardiomiocituose, todėl stiprina } \\
\text { širdies kontraktinę funkciją; } \\
\text { Sumažejus kalcio kiekiui, kraujagyslių } \\
\text { lygiuosiuose raumenyse pasireiškia } \\
\text { vazodilatacija }\end{array}$ & 2 val. & $\begin{array}{l}\text { Skilvelinès arit- } \\
\text { mijos, hipoten- } \\
\text { zija, torsades de } \\
\text { pointes }\end{array}$ \\
\hline $\begin{array}{l}\text { Levosimenda- } \\
\text { nas }\end{array}$ & $\begin{array}{l}\text { Didina troponino C } \\
\text { jautrumą intraląste- } \\
\text { liniam kalciui }\end{array}$ & $\begin{array}{l}\text { Boliusas } 6-24 \mu \mathrm{g} / \\
\mathrm{kg} \text { kartu su } 0,1-0,4 \\
\mu \mathrm{g} / \mathrm{kg} / \mathrm{min} \text { infuzija } \\
6 \text { val. }\end{array}$ & $\begin{array}{l}\text { - Inotropija ir inodilatacija } \\
\text { - Kalcio jautrintojas, kuris stiprina } \\
\text { širdies kontraktilinę } \\
\text { funkciją, didindamas miokardo jau- } \\
\text { trumą kalciui } \\
\text { - Veikia ATP valdomus K+ kanalus, } \\
\text { todėl atsipalaiduoja kraujagyslių lygieji } \\
\text { raumenys, pasireiškia koronarų ir peri- } \\
\text { ferinė vazodilatacija }\end{array}$ & $\begin{array}{l}1 \text { val. (me- } \\
\text { tabolitai iki } \\
80 \text { val.) }\end{array}$ & $\begin{array}{l}\text { Tachikardija, } \\
\text { hipotenzija, } \\
\text { sustiprèjęs AV } \\
\text { laidumas }\end{array}$ \\
\hline
\end{tabular}


Remiantis EKD 2021 m. gairemis, trumpalaikès MKPP KŠ atveju indikuotinos, kai yra kritinė organų-taikinių hipoperfuzija bei hipoksija ir naudojamos ribotą laiką, nuo kelių dienų iki keleto savaičių. Trumpalaikès MKPP gali būti taikomos kaip tiltas i pasveikimą (angl. bridge to recovery, BTR), tiltas i sprendimą (angl. - bridge to decision, BTD), tiltas ị tiltą (angl. bridge to bridge, BTB) (IIa klasé, C ịrodymų lygis). Ilgalaikès MKPP turètų būti apsvarstytos atrinktiems pacientams, kai medikamentinis gydymas arba trumpalaikès MKPP yra nepakankamai efektyvios (1 lentelè) [1]. MKPP parenkamos atsižvelgiant i INTERMACS (angl. The Interagency Registry for Mechanically Assisted Circulatory Support) profili. Tokia klasifikacija padeda įvertinti pacientų, kuriems atliekama skubi širdies transplantacija arba KSPP implantacija, prognozę ir pacientų su pažengusiu ŠN riziką [1].

Remiantis randomizuoto IABP-SHOCK-II tyrimo duomenimis, KŠ pacientų po ŪMI, kuriems atlikta ankstyva revaskuliarizacija, 30 dienų (IABP gr. 39,7\% vs kontrolinè gr. $41,3 \%$ ) ir 6 metų (IABP gr. $66,3 \%$ vs kontrolinè gr. $67 \%$ ) išgyvenamumas taikant optimalų medikamentini gydymą arba IABK nesiskyrè, todèl IABK rutiniškai nèra rekomenduojamas KŠ gydymui po ŪMI (III klasè, B įrodymų lygis) [1,15].

Charlene L. Rohm ir kt. atliktoje retrospektyvinèje studijoje nagrinejjama 276 pacientų, kuriems 2011-2020 m. dèl KŠ taikyta Impella, t. y. mikroaksialinis skilvelius pavaduojantis prietaisas, imtis. Pastebèta, kad priešingai nei inotropų, kiekvieno vazopresoriaus skyrimas susijęs su didesniu mirtingumu, iš kurių didžiausia rizika pasižymèjo NE. Atsižvelgiant $i \underset{\text { tai, }}{\mathrm{k} a d}$ mirtingumas skiriant $\geq 3$ vazopresorius ir inotropus reikšmingai padidèja ( 0 -2 vaistų gr. $8,1 \%$ vs 3 vaistu gr. 39,7\%, p<0,001), Impella taikymas turètų būti apsvarstytas, jei KS̆ gydymas 1 inotropu ir 1 vazopresoriumi yra neveiksmingas. Tyrimo rezultatai parode, kad pacientų su KS ir Impella mirtingumas vartojant tam tikrus vazopresorių ir inotropų derinius yra didesnis. Palyginus KŠ gydymą 1 vazopresoriumi ir 2 inotropais su 2 vazopresoriais ir 1 inotropu, buvo nustatyta, kad skiriant kelis inotropus mirtingumas reikšmingai padidejja $(\mathrm{p}=0,019)$, o tai gali būti susiję su galimomis komplikacijomis, tokiomis kaip tachiaritmijos, padidèjęs miokardo deguonies suvartojimas ir sutrikęs širdies raumens atsikūrimas. Pastebèta, kad 3 vazopresorių naudojimas yra susijęs su didesniu mirtingumu, nei gydant 2 vazopresoriais ir 1 inotropu $(\mathrm{p}=0,022)$. Mirtingumas nuo KŠ́ gydant dobutaminu arba milrinonu $(\mathrm{p}=0,544), 2$ vazopresoriais arba 1 vazopresoriumi ir 1 inotropu tarp grupių statistiškai reikšmingai nesiskyre $(\mathrm{p}=0,821)$. Remiantis studijos duomenimis, inotropai turètų būti pirmo pasirinkimo vaistais KŠ metu, tačiau jei paskyrus 1 inotropą ir 1 vazopresorių bei
Impella (ir (ar) >4 dienos) hemodinamika išlieka nestabili, reikètų apsvarstyti papildomų MKPP taikymą [9]. Panašius duomenis aprašo ir kiti tyrèjai. Atsižvelgus i Andrew M. Goldsweig ir kt. NCSI (angl. The National Cardiogenic Shock Initiative) pacientu su ūmiu koronariniu sindromu, kuris komplikavosi KS ir buvo taikytos MKPP, analizès duomenis, nustatyta, kad geresnis MKPP ir (ar) perkutanine koronarografija gydytų pacientų išgyvenanumas susijęs su mažesniu inotropų skyrimu, atlikta pilna revaskuliarizacija bei didesniu ŠMT po Impella naudojimo [16].

Nicolas Bréchot ir kt. tarptautiniame retrospektyviniame tyrime buvo vertinamas sepsio sukelto KŠ gydymas VA EKMO (82 VA -EKMO gr. ir 130 kontrolinè gr.). Pacientu, gydytų VA-EKMO, 90 dienų išgyvenamumas buvo didesnis, nei kontrolinès grupès (VA - EKMO gr. $60 \%$ vs $25 \%$ kontrolinè gr.). VA-EKMO taikymas padèjo greitai sumažinti vazopresorių dozę, o sparti laktato korekcija - atkurti gyvybiški svarbių organų perfuziją. Su VA-EKMO susijusi komplikacija pasireiškẻ beveik pusei pacientų, iš kurių dažniausia - kraujavimas kaniulès isstūmimo vietoje. Reikia pabrèžti, kad tai ne kontrolinis atsitiktinių imčių tyrimas: VA-EKMO pacientai buvo jaunesni (44 m. vs $66 \mathrm{~m}$. kontrolinè gr.), su sunkesne miokardo disfunkcija (vidutinis ŠI $1,5 \mathrm{l} / \mathrm{min} / \mathrm{m}^{2}$ vs $2,2 \mathrm{l} / \mathrm{min} / \mathrm{m}^{2}$, KSIF $17 \%$ vs $27 \%$ ), prastesne hemodinamika (inotropai $279 \mu \mathrm{g} / \mathrm{kg} / \mathrm{min}$ vs $145 \mu \mathrm{g} / \mathrm{kg} / \mathrm{min}$, serumo laktatas $8,9 \mathrm{mmol} / \mathrm{l}$ vs $6,5 \mathrm{mmol} / \mathrm{l})$, labiau pažengusiu vidaus organy nepakankamumu (SOFA balai 17 vs 13), todèl išvados turètu būti interpretuojamos atsakingai [17].

Nors įvairios etiologijos KS̆ gydymui vis dažniau naudojamos MKPP, pacientams, sergantiems sunkiomis širdies ligomis, efektyviausias gydymo būdas yra širdies persodinimas. Pirmają širdies transplantaciją medicinos istorijoje 1967 m. Keiptaune atliko Christian M. Bernard. Operacijos metu širdis buvo persodinta išemine kardiomiopatija sergančiam pacientui [18]. Pirmają širdies transplantaciją Lietuvoje 1987 m. atliko prof. A. Marcinkevičius. Remiantis Nacionalinio transplantacijos biuro duomenimis, šiuo metu (2021 m. lapkritis) širdies transplantacijos Lietuvoje laukia 55 asmenys, iš kurių 4 vaikai. Dėl vis prastejančios ar kritinès pacientų būklès ir tinkamų organų donorų trūkumo reikalingos papildomos alternatyvos, todèl tiltu ị širdies transplantaciją tampa dirbtiniai skilveliai. Tai ilgalaike MKPP, kurios pradininku ir moderniosios kardiochirurgijos tèvu laikomas širdies ir kraujagyslių chirurgas M. DeBakey. Jis 1966 m., 10 dienų iki širdies transplantacijos, pirmą kartą sẻkmingai pritaikẻ KSPP (angl. left ventricular assist device, LVAD) (2 lentelè) [19]. Jei širdies transplantacija negalima, KSPP gali būti naudojamas ilgalaikiam terminalinès būklès pacientų gydymui (angl. destination therapy) (1 lentelè) $[1,19]$. 


\section{Išvados}

1. Esant hipotenzijai ar vazoplegijai pirmo pasirinkimo vaistas - norepinefrinas, jei kraujospūdis normalus - inotropai.

2. Norepinefrino skyrimas susijęs su mažesniu pacientų mirtingumu, retesnèmis aritmijomis ir rečiau išsivystančiu refrakteriniu kardiogeniniu šoku.

3. Norepinefrino ir levosimendano ar dobutamino kombinacija yra tinkama kardiogeninio šoko gydymui.

4. Epinefrinas dèl $\alpha$ ir $\beta$ adrenerginio poveikio miokardui yra mažiausiai saugus ir susijęs su didesniu mirtingumu.

5. Dopaminas susijęs su dažnesnèmis aritmijomis, tachikardijomis ir didesniu mirtingumu.

6. Levosimendanas pasižymi teigiamu inotropiniu poveikiu ir Tako-Tsubo kardiomiopatija gali būti skiriamas kaip alternatyva katecholaminams.

7. Impella taikymas turètų būti apsvarstytas, jei kardiogeninio šoko gydymas 1 inotropu ir 1 vazopresoriumi yra neveiksmingas.

\section{Literatūra}

1. McDonagh TA, Metra M, Adamo M, Gardner RS, Baumbach A, Böhm M, et al. 2021 ESC Guidelines for the diagnosis and treatment of acute and chronic heart failure: Developed by the Task Force for the diagnosis and treatment of acute and chronic heart failure of the European Society of Cardiology (ESC) With the special contribution of the Heart Failure Association (HFA) of the ESC. Eur Heart J 2021;42(36):3599-726.

https://doi.org/10.1093/eurheartj/ehab368

2. Karami M, Hemradj VV, Ouweneel DM, den Uil CA, Limpens J, Otterspoor LC, et al. Vasopressors and Inotropes in Acute Myocardial Infarction Related Cardiogenic Shock: A Systematic Review and Meta-Analysis. J Clin Med 2020;9(7):2051. https://doi.org/10.3390/jcm9072051

3. Manolopoulos PP, Boutsikos I, Boutsikos P, Iacovidou N, Ekmektzoglou K. Current use and advances in vasopressors and inotropes support in shock. J Emerg Crit Care Med 2020;4:20-20.

https://doi.org/10.21037/jeccm.2019.12.03

4. Cotinet P-A, Bizouarn P, Roux F, Rozec B. Management of cardiogenic shock by circulatory support during reverse TakoTsubo following amphetamine exposure: A report of two cases. Heart Lung 2021;50(3):465-9.

https://doi.org/10.1016/j.hrtlng.2020.10.007

5. Shabana A, Dholoo F, Banerjee P. Inotropic Agents and Vasopressors in the Treatment of Cardiogenic Shock. Curr Heart Fail Rep 2020;17(6):438-48. https://doi.org/10.1007/s11897-020-00493-9

6. Amado J, Gago P, Santos W, Mimoso J, de Jesus I. Cardiogenic shock: Inotropes and vasopressors. Rev Port Cardiol Engl Ed 2016;35(12):681-95 https://doi.org/10.1016/j.repc.2016.08.004

7. Uhlig K, Efremov L, Tongers J, Frantz S, Mikolajczyk R, Sedding D, et al. Inotropic agents and vasodilator strategies for the treatment of cardiogenic shock or low cardiac output syndrome. Cochrane Database Syst Rev 2020. https://doi.org/10.1002/14651858.CD009669.pub4

8. Scheeren TWL, Bakker J, Kaufmann T, Annane D, Asfar P, Boerma EC, et al. Current use of inotropes in circulatory shock. Ann Intensive Care 2021;11(1):21. https://doi.org/10.1186/s13613-021-00806-8

9. Rohm CL, Gadidov B, Ray HE, Mannino SF, Prasad R. Vasopressors and inotropes as predictors of mortality in acute severe cardiogenic shock treated with the Impella device. Cardiovasc Revasc Med 2020;S1553838920307843.

https://doi.org/10.1016/j.carrev.2020.12.001

10. Levy B, Clere -Jehl Raphael, Legras A, Morichau -Beauchant Tristan, Leone M, Frederique G, et al. Epinephrine Versus Norepinephrine for Cardiogenic Shock After Acute Myocardial Infarction. J Am Coll Cardiol 2018;72(2):173-82. https://doi.org/10.1016/j.jacc.2018.04.051

11. Levy B, Buzon J, Kimmoun A. Inotropes and vasopressors use in cardiogenic shock: when, which and how much? Curr Opin Crit Care 2019;25(4):384-90.

https://doi.org/10.1097/MCC.0000000000000632

12. Levy B, Klein T, Kimmoun A. Vasopressor use in cardiogenic shock. Curr Opin Crit Care 2020;26(4):411-6.

https://doi.org/10.1097/MCC.0000000000000743

13. Nobian A, Mohamed A, Spyridopoulos I. The role of arginine vasopressin in myocardial infarction and reperfusion. Kardiologia Pol Pol Heart J 2019;77(10):908-17.

https://doi.org/10.33963/KP.14986

14. Ibanez B, James S, Agewall S, Antunes MJ, Bucciarelli-Ducci C, Bueno H, et al. 2017 ESC Guidelines for the management of acute myocardial infarction in patients presenting with STsegment elevation: The Task Force for the management of acute myocardial infarction in patients presenting with ST-segment elevation of the European Society of Cardiology (ESC). Eur Heart J 2018;39(2):119-77.

https://doi.org/10.1093/eurheartj/ehx393

15. Thiele H, Zeymer U, Thelemann N, Neumann F-J, Hausleiter J, Abdel-Wahab M, et al. Intraaortic Balloon Pump in Cardiogenic Shock Complicating Acute Myocardial Infarction. Circulation 2019;139(3):395-403.

https://doi.org/10.1161/CIRCULATIONAHA.118.038201

16. Goldsweig AM, Tak HJ, Alraies MC, Park J, Smith C, Baker J, et al. Mechanical Circulatory Support Following Out-of-Hospital Cardiac Arrest: Insights From the National Cardiogenic Shock Initiative. Cardiovasc Revasc Med 2021;32:58-62. https://doi.org/10.1016/j.carrev.2020.12.021

17. Bréchot N, Hajage D, Kimmoun A, Demiselle J, Agerstrand C, Montero S, et al. Venoarterial extracorporeal membrane 
oxygenation to rescue sepsis-induced cardiogenic shock: a retrospective, multicentre, international cohort study. The Lancet 2020;396(10250):545-52. https://doi.org/10.1016/S0140-6736(20)30733-9

18. Stolf NAG. History of Heart Transplantation: a Hard and Glorious Journey. Braz J Cardiovasc Surg 2017;32(5):423-7. https://doi.org/10.21470/1678-9741-2017-0508

19. Chair SY, Yu DS, Ng MT, Wang Q, Cheng HY, Wong EM, et al. Evolvement of left ventricular assist device: the implications on heart failure management. J Geriatr Cardiol 2016;13(5):425-30.

MODERN TREATMENT OF CARDIOGENIC SHOCK I. Rudinskaitė, G. Navickas, R. S. Samalavičius, P. Šerpytis

Keywords: cardiogenic shock, inotropes, vasopressors, sympathomimetics.

Summary

Cardiogenic shock (CS) - is a clinical condition characterized by decreased cardiac output, hypoperfusion, multiple organ failure, and high mortality. Acute myocardial infarction is the leading cause of CS, accounting for about one-third of all CS cases. The clinical definition of CS is mostly based on hemodynamic criteria and signs of hypoperfusion. In order to restore hemodynamics and improve organ perfusion vasopressors and inotropes are used. The scientific literature indicates that norepinephrine is a first-line treatment for CS and inotropes are added if low cardiac output persists.
Aim: to analyse a modern treatment of cardiogenic shock in various scientific literature from 2016 to 2021.

Methods: the systematic review was performed. Data were collected from PubMed, ScienceDirect, ClinicalKey, Cochrane Library databases. 19 full-text articles in English from 2016 to 2021 were selected and analyzed.

Results: In case of hypotension or vasoplegia, norepinephrine is the first-line treatment and inotropes are used if blood pressure is normal. According to the literature, norepinefrine is associated with less frequent arrhythmias, less likely refractory shock and decreased mortality in CS. A combination of norepinefrine and levosimendan/dobutamine is suitable for the treatment of CS. Epinefrine due to its $\alpha$ and $\beta$ adrenergic effects on the myocardium has the worst safety profile and is associated with higher mortality rates. Dopamine is associated with increased arrhythmias, tachycardia and mortality. Studies showed that levosimendan has a positive inotropic effect and can be used as an alternative to catecholamines in Tako-tsubo cardiomyopathy. However, there is still a lack of randomized controlled studies analyzing different medication therapies for CS.

Correspondence to: ievarudinskaite@gmail.com

Gauta 2021-11-08 